\title{
Análise discursiva de apresentações de livros didáticos de inglês em manuais do professor com base na Lingúistica Sistêmico-Funcional
}

\author{
Renato Caixeta da Silva \\ Cefet - MG
}

\begin{abstract}
Resumo
Este trabalho analisa apresentações de livros didáticos de inglês brasileiros contidas em manuais endereçados aos professores da área e escritas por autores ou editores desses livros. A análise discursiva é baseada na Linguística SistêmicoFuncional. O livro didático de inglês é visto, aqui, como um elemento do cotidiano social, com importância pedagógica, política, econômica e social, não apenas um instrumento de ensino de línguas, o que também norteia a análise a ser apresentada. Os dados mostram, dentre outras coisas, o caráter agentivo conferido ao livro didático no processo ensino-aprendizagem de língua inglesa, e ainda outros objetivos que simplesmente apresentar a coleção didática.
\end{abstract}

Palavras Chave: livros didáticos, manual do professor, Linguística SistêmicoFuncional

\begin{abstract}
This article analyzes EFL course book presentations located in teachers' manuals, which are written by either the authors or the editors. The analysis of the discourse is based on Systemic-Functional Linguistics. In this study, EFL course books are seen as social elements with pedagogic, political, economic and social importance, rather than just a language teaching instrument, and the analysis is guided by this view. The findings reveal that, while there is the objective of simply presenting the collection, beyond this, the course book is attributed the role of agent in the EFL teaching and learning process.
\end{abstract}

Keywords: Course books, Teachers’ Manuals, Systemic-Functional Linguistics

\section{INTRODUÇÃO}

Este trabalho tem como objetivo analisar apresentações de livros didáticos de inglês destinadas a professores e localizadas em manuais endereçados a estes profissionais (os livros do professor) à luz dos conceitos da Linguística Sistêmico-Funcional. Primeiramente, apresentarei o arcabouço teórico ressaltando a visão sócio-semiótica da linguagem apresentada pela LSF, as metafunções da linguagem, a noção de contexto de situação e de cultura, os sistemas de significação textual, ideacional e interpessoal (Halliday\&Hasan, 1989; Halliday, 1994 e Halliday\&Mathiessen, 2004), a proposta de análise discursiva de Martin \& Rose (2003) e o conceito de gêneros discursivos proposto por adeptos da Linguística Sistêmica Funcional (Martin, 1997, Eggins\& Martin, 1996, Hasan, 1989). Em seguida, 
procuro caracterizar o gênero apresentações de livros didáticos de inglês com base em leitura de textos desta natureza veiculados em livros de professores de coleções didáticas de inglês editadas no Brasil, consequentemente escritos em português.

Mais adiante, faço uma análise discursiva considerando duas apresentações de livros didáticos nacionais contidas nos respectivos manuais endereçados ao professor. Este é um ensaio de uma pesquisa maior para doutoramento, em que pretendo investigar as representações construídas por autores, editores e professores de livros didáticos de inglês (internacionais e nacionais).O presente trabalho pode contribuir no sentido de promover reflexões acerca desta proposta, e conscientização a respeito das possibilidades e dos problemas inerentes à pesquisa. Acredito que este trabalho também contribui para a aplicação da teoria sistêmica da linguagem ao português brasileiro na medida em que esses textos refletem o uso real da língua portuguesa com o intuito de agir na sociedade brasileira, apresentando o livro didático em questão, esclarecendo e orientando professores a seu respeito.

É necessário ressaltar pontos que justificam tanto a pesquisa acima mencionada quanto este trabalho. Em primeiro lugar, proponho-me a analisar textos que podem ser referências para a escolha e o uso de materiais de ensino de língua inglesa, e que contribuem para a construção de representações acerca do livro didático por parte do autor, do editor (seus autores) e do professor (seu receptor). Além disso, e mais especificamente, analisar o discurso veiculado pelos manuais endereçados aos professores também se justifica por ser este o ou um dos recursos principais que muitos profissionais utilizam quando não podem frequentar cursos de formação e desenvolvimento profissional (Cunningsworth, 1995).

Ao mesmo tempo, acredito que a pesquisa descrita brevemente acima pode contribuir para uma interseção das idéias levantadas pelos estudos sobre o discurso e estudos referentes ao ensino de línguas, pois adoto referenciais teóricos de estudos discursivos baseados na Linguística Sistêmico-Funcional para analisar discursos sobre um objeto importante do fazer pedagógico do professor de inglês como língua estrangeira, o livro didático. Outra interseção a ser considerada com esta pesquisa refere-se à consequente ligação dessas áreas com o campo de estudo das representações, enfatizando a importância de investigações sobre o discurso na detecção de representações.

É importante frisar que, tanto neste presente trabalho quanto na proposta de doutorado mencionada, entendo o livro didático de inglês como um elemento do cotidiano social, com importância pedagógica, política, econômica e social. Trata-se de uma investigação não sobre 
elementos do livro didático ou metodologias e abordagens veiculadas, mas sobre o livro em si.

\section{A LINGUÍSTICA SISTÊMICO-FUNCIONAL E A VISÃO SOCIOSSEMIÓTICA DA LINGUAGEM.}

A Linguística Sistêmico-Funcional considera a língua como um sistema no qual usuários fazem escolhas para a produção de significado (Neves, 2004), o que leva a uma ação social. O interesse dos linguistas sistêmicos é no uso da linguagem em contexto social e esse uso da língua / linguagem é funcional, sendo a função primeira da linguagem produzir significados. Os usuários da língua fazem escolhas dentro do sistema linguístico de acordo com o contexto em que ocorre a comunicação. A visão hallidiana toma a língua como sistema de significação (semiótico) que, juntamente com outros sistemas semióticos, constitui a cultura humana (Halliday, 1989).

Eggins (1994) evidencia quatro pontos teóricos importantes sobre a linguagem dentro da Linguística Sistêmico-Funcional, a saber: o uso da língua / linguagem é funcional; sua função primordial é produzir significados; esses significados são influenciados pelo contexto social e cultural de negociação; e o processo de uso da linguagem é semiótico.

Halliday (1994) diz que esta é uma abordagem que segue a tradição funcionalista de estudos linguísticos européia, e ao mesmo tempo é sistêmica porque considera que a produção de significado é fruto de escolhas (nem sempre conscientes) dentro de uma rede de opções (que é a própria língua). A língua, então, é uma rede de sistemas, e dentro desses sistemas há um conjunto de alternativas possíveis numa relação paradigmática (“o que poderia ser ao invés de...”) ${ }^{1}$.Através das escolhas são formadas as estruturas numa ordem sintagmática, que revelam o aspecto composicional da língua e que seguem o princípio de ordenamento (“o que vai junto com”) ${ }^{2}$.

A língua enquanto sistema semiótico é complexa e tem vários níveis - estratos. No nível da expressão há os aspectos fonéticos / fonológicos em se tratando de oralidade ou o grafológico considerando a língua escrita. O nível de conteúdo se divide entre os aspectos léxico-gramaticais e, num patamar acima, os aspectos semânticos discursivos. Além desses estratos da língua propriamente dita, está o contexto social, que se subdivide em de situação e de cultura.

\footnotetext{
${ }^{1}$ Explicação presente em Halliday\&Mathiessen, 2004.

${ }^{2}$ Idem
} 
Entendido de maneira mais abrangente, o texto é uma unidade de significado em que são usados recursos semióticos, linguísticos e não linguísticos. Halliday\&Mathiessen (2004) definem texto como um exemplar de língua que faz sentido a uma pessoa que conhece a língua, um fenômeno rico gramaticalmente, multifacetado, que pode ser duradouro ou efêmero, momentâneo ou trivial, memorável ou facilmente esquecido. Enfocá-lo como objeto implica em tentar encontrar informações quanto ao que ele significa, o que mostra, o que faz, qual seu valor. Enquanto instrumento, por outro lado, um texto pode revelar informações sobre a língua e seu funcionamento.

\section{O Contexto}

Halliday parte do conceito de contexto de Malinowsky para assumir que os textos acontecem em ambientes sociais, e que há um relacionamento estreito entre esse ambiente social e a organização funcional da língua. Daí, pode-se dizer que o contexto de situação (esse ambiente) em que acontece uma interação linguística dá aos participantes dessa interação muita informação a respeito dos significados ali construídos e negociados. Ao mesmo tempo, os significados construídos na interação podem dar informação a respeito do contexto (Halliday\&Hasan, 1989; Martin, 1997).

As variáveis do contexto de situação são o campo (natureza da atividade social, as ações, seus participantes e circunstâncias), as relações entre os participantes (hierarquia, papéis, distância social), e modo (canal de comunicação, media, papel da linguagem).

Porém, além desse ambiente em que se insere um texto, nas trocas linguísticas há histórias culturais dos participantes envolvidos e dos tipos de práticas em que eles se engajam. Isso determina a significância do texto ou da interação para a cultura, seja em caráter prático ou ritualístico. Daí surge a noção de contexto de cultura.

Martin (1997) acrescenta que o contexto social também é estratificado, estando dividido em contexto de registro/ situação e contexto de cultura. Acima desses dois ainda estaria a ideologia. Essa estratificação do contexto será importante para o entendimento da definição de gênero dentro da Linguística Sistêmico-Funcional, exposta mais adiante.

No caso da pesquisa aqui em questão, o campo é o ensino de língua inglesa como língua estrangeira, contexto dentro do qual acontecem as atividades de produção, comercialização, escolha e utilização de materiais didáticos (mais especificamente o livro didático). As relações 
estabelecidas entre autores / editores $^{3}$ e professores em textos de apresentação de livros didáticos veiculados em manuais do professor é a de oferta de um produto e de informações a respeito do mesmo. Alguém que necessita de um livro para organizar o trabalho docente recebe informações de alguém que deseja ter o livro adotado, comprado, e elabora um texto com tendências publicitárias para convencer o leitor das vantagens daquele material em questão. Pode haver também uma proximidade estabelecida pelo uso de pronomes como nós e você, uma forma de o autor / editor se mostrar como identificado com o profissional e seu trabalho. A linguagem escrita é o modo como comunicação acontece. A mensagem é transmitida através do meio impresso (livro), pode ou não ter imagens, é organizada em tópicos, com linguagem sintética e clara para que o professor, atraído, possa ter informações mais rapidamente.

\section{As Metafunções}

São consideradas três metafunções do uso da linguagem pelos seres humanos no meio social: falar de experiências externas e internas do mundo circundante (metafunção ideacional), estabelecer relações com outras pessoas no meio social (metafunção interpessoal), e organizar a mensagem para com ela agir através da criação de sentidos (metafunção textual) ${ }^{4}$. Segundo Neves (2004), as metafunções ideacional e interpessoal representam os propósitos gerais de todos os usos da linguagem, a saber, entender o ambiente / contexto e influir sobre outras pessoas.

A metafunção ideacional se constitui no uso da língua para representar a realidade, e nesta representação estão envolvidos participantes, processos, e circunstâncias. Construir a experiência humana através do uso da língua implica em nomear e registrar processos, nomear e categorizar seres participantes desses processos, identificar as circunstâncias que permeiam os processos (Halliday\&Mathiessen, 2004).

Em termos interpessoais, o uso da língua revela as relações humanas construídas na interação; o papel do falante é definido em relação ao seu interlocutor e em sintonia com o que é comunicado e negociado em termos de sentidos (Halliday\&Mathiessen, 2004).

\footnotetext{
${ }^{3}$ Uso o termo autor / editor considerando que tanto o autor da obra quanto o editor podem escrever textos de apresentação. Algumas vezes é explícita a assinatura do editor (como na Coleção MUST), e existem textos em que fotos dos autores são incluídos, dando a entender que eles seriam os autores desses textos também. No caso da Coleção Power English, na carta endereçada ao professor há constante uso de "nós" indicando que esses autores se identificam também com os professores, que se incluem como tais profissionais, mas não há assinatura. Ver adiante.

${ }^{4}$ Definição parafraseada de Magalhães, 2006.
} 
Por sua vez, a metafunção textual confere relevância às outras duas, uma vez que o texto / mensagem é a unidade maior de análise, de acordo com a LSF. A ênfase aqui está na construção do texto, nas sequências discursivas, no fluxo da informação, na coesão (Halliday\&Mathiessen, 2004).

Embora pareçam coisas muito distintas, não são estanques; acontecem juntas a um só tempo. Usar a língua implica em produção de significados ideacionais, interpessoais, e textuais em conjunto. Difícil, porém, é explicar sem uso da separação para fins didáticos no momento de descrição do uso da língua.

As variáveis do contexto estão paralelamente relacionadas com as três metafunções da linguagem (Martin, 1997; Eggins\& Martin, 1996). Assim, a metafunção ideacional está voltada para o campo, a metafunção interpessoal é ligada às relações, e a metafunção textual relaciona-se com o modo.

Acredito que, ao produzirem e divulgarem textos de apresentação de um livro didático, editores e autores têm em mente a produção de um texto que pode ajudar ou direcionar a adoção e o uso daquele material por um professor, uma escola ou até mesmo um sistema de ensino. Sendo assim, os produtores destes textos (nem sempre identificáveis) fazem escolhas linguísticas de acordo com os objetivos comercial e pedagógico que permeiam o contexto. Como visto mais adiante, nesses textos há uma ênfase na descrição do material e seus componentes (a função ideacional) e na relação de certeza e segurança a ser estabelecida com o leitor-professor (função interpessoal). Ao mesmo tempo, há uma preocupação em organizar o texto de modo a conferir ênfase à coleção didática em si e seus componentes, moldar a mensagem- texto escrito -de acordo com os objetivos de persuasão e com o canal (papel), fazendo-o mais conciso e de fácil entendimento (função textual).

\section{Os Sistemas de Significação}

\section{a) Ideacional - representação}

A língua capacita o ser humano a representar a realidade que o circunda, a fazer sentido do que acontece dentro de si e ao seu redor, e, gramaticalmente, isso se realiza na língua através do sistema de transitividade (Halliday, 1994). No nível oracional, este sistema permite reflexão e imposição de ordem às variações e fluxos de eventos (Halliday, 1994; Halliday\&Mathiessen, 2004). Pela transitividade, o mundo das experiências é construído através da expressão de processos - o elemento mais central desta configuração. Há os participantes- cujas naturezas variam de acordo com os processos em que estiverem 
envolvidos, e as circunstâncias - que não variam necessariamente de acordo com o processo, e que não estão ligados a ele diretamente.

O quadro abaixo é uma tentativa de sistematizar e sintetizar os processos e seus participantes.

\begin{tabular}{|l|l|l|}
\hline \multicolumn{2}{|c|}{ Processos } & \multicolumn{1}{c|}{ Participantes } \\
\hline $\begin{array}{l}\text { Materiais } \\
\text { (processo de fazer) }\end{array}$ & $\begin{array}{l}\text { Criativos } \\
\text { Tranformativos }\end{array}$ & $\begin{array}{l}\text { Ator - quem faz } \\
\text { Meta - quem sofre a ação }\end{array}$ \\
\hline $\begin{array}{l}\text { Mentais } \\
\text { sentir, pensar, perceber) }\end{array}$ & $\begin{array}{l}\text { Sensor - quem sente, pensa , } \\
\text { percebe; humano } \\
\text { Fenômeno - o que é sentido, } \\
\text { percebido, pensado }\end{array}$ \\
\hline $\begin{array}{l}\text { Relacionais- Identificador } \\
\text { ( o ser) - Atributivo }\end{array}$ & $\begin{array}{l}\text { Intensivo } \\
\text { Circunstancial } \\
\text { Possessivo }\end{array}$ & $\begin{array}{l}\text { Portador e Atributo,ou } \\
\text { Identificado e Identificador,ou } \\
\text { Característica e Valor }\end{array}$ \\
\hline $\begin{array}{l}\text { Comportamentais } \\
\text { comportamentos psicológicos e } \\
\text { comportamentais) }\end{array}$ & $\begin{array}{l}\text { Comportante - serhumano } \\
\text { Comportamento }\end{array}$ \\
\hline $\begin{array}{l}\text { Verbais } \\
\text { (o dizer, o significar - trocas } \\
\text { simbólicas) }\end{array}$ & $\begin{array}{l}\text { Dizente - quem produz a } \\
\text { mensagem } \\
\text { Verbiagem - a mensagem } \\
\text { Receptor - quem recebe a } \\
\text { mensagem }\end{array}$ \\
\hline $\begin{array}{l}\text { Existenciais } \\
\text { (o vir a ser, existir, ocorrer) }\end{array}$ & & \begin{tabular}{l} 
Existente \\
\hline
\end{tabular} \\
\hline
\end{tabular}

Quadro 1 - Processos e participantes - significados ideacionais. Fonte Halliday (1994); Hallliday\&Mathiessen (2004)

Ainda podem ocorrer outros tipos de participantes, a saber:

Beneficiário, que em processos materiais pode ser cliente (para quem se faz algo) ou recipiente (a quem se dá algo), e que em processos verbais seria a entidade a quem se endereça a mensagem.

Range ou escopo: que em processos materiais e comportamentais pode ser o domínio a que pertence o processo ou o processo em si, e que em processos mentais a interrelação entre o fenômeno e um de seus elementos estruturais.

A seguir, apresento uma sistematização e síntese das circunstâncias consideradas em Halliday (1994), e Halliday\&Mathiessen (2004).

\begin{tabular}{|l|l|}
\hline Tipos de circunstâncias & Categoriasespecíficas \\
\hline Extensão & Distância, duração (tempo e espaço) \\
\hline Localização & Lugar, tempo \\
\hline Modo & Meio, qualidade, comparação \\
\hline Causa & Razão, propósito, em lugar de \\
\hline Contingência & Condição, concessão, “default” \\
\hline Companhia & Concomitância, adição \\
\hline
\end{tabular}




\begin{tabular}{|l|l|}
\hline Papel & "guise", produto \\
\hline Assunto & \\
\hline Ângulo & \\
\hline
\end{tabular}

Quadro 2 - Circunstâncias: significadosideacionais

\section{b) Interpessoal - troca}

A consideração de aspectos interpessoais de significação inclui os papéis comunicativos criados pela linguagem, isto é, “os papéis de 'perguntador' e 'respondente', que assumimos ao fazer uma pergunta e respondê-la; e também para conseguir que coisas sejam feitas, pela interação entre uma pessoa e outra” (Schlee, 2006: 1007). Numa interação, segundo Hallliday (1994), os participantes assumem os papéis de dar ou demandar informações ou bens e serviços. O autor esclarece ainda que o ato de dar do falante ou escritor implica em receber por parte de seu interlocutor, da mesma forma que o ato de demandar implica em dar. $\mathrm{O}$ quadro a seguir pode ajudar a visualizar essa troca, ao mesmo tempo em que mostra a categorização apresentada por Halliday.

\begin{tabular}{|l|l|l|}
\hline “commodity” negociada & Bens e serviços & Informação \\
\hline Papel na troca & & \\
\hline Dar & Oferecimento & Declaração \\
\hline Demandar & Comando & Pergunta \\
\hline
\end{tabular}

Quadro 3 - Papéis discursivos dos interlocutores: significado interpessoal

Em se tratando de bens e serviços, a ação esperada é não verbal, a função semântica da oração é uma proposta, e a língua é meio para atingir propósitos não-verbais. No caso de informações, a ação esperada é verbal, e semanticamente a oração é uma proposição.

Em termos interpessoais, o sistema de significação a ser considerado em análises é o de Modo Oracional e de Modalidade. Por Modo Oracional, Halliday (1994) entende que seja o componente central da troca de "commodity”, aquele que expressa o argumento da oração, que mostra a seleção do modo verbal, carrega a carga da oração como evento interativo (sua função semântica). Sua composição é expressa pelo esquema seguinte:

Modo = Sujeito + Finito (operador verbal)

grupo nominal; elemento recuperado pelo finito ou pronome numa "tagquestion"; entidade que o falante quer fazer responsável pela validade da proposta ou proposiçãoexpressa na oração. parte do grupo verbal: em português é expresso na forma de desinências verbais ou verbos auxiliares;elemento que torna possível a negociação da validade da proposta ou proposição: em que tempo é válida (tempo verbal), se é positiva ou negativa (polaridade), a extensão da validade (modalidade)

Figura 1 - A estrutura Modo Oracional: significado interpessoal 
O restante da oração, o que não é Modo, é o Resíduo, composto por um predicador - o restante do grupo verbal sem o elemento finito, e que expressa o processo em si, tempo secundário e conclusibilidade; complementos - grupo nominal que poderia ser Sujeito exceto se for o complemento atributivo em processos relacionais; e adjuntos- circuntanciais, sintagma preposicional ou grupo adverbial

Importante aqui também são as noções de polaridade e de modalidade, ambos expressos no Modo Oracional. Por polaridade entende-se a dualidade entre positivo e negativo - o sim e o não, sendo que o negativo em português é expresso também por palavras como 'nunca', 'nada'. A modalidade, por sua vez, é o espaço entre o sim e o não; os graus intermediários entre o positivo e o negativo, e divide-se em modalização quando há negociação de informação (proposição), e modulação quando há negociação de bens e serviços (proposta). O esquema a seguir mostra as formas de expressão de modalidade.

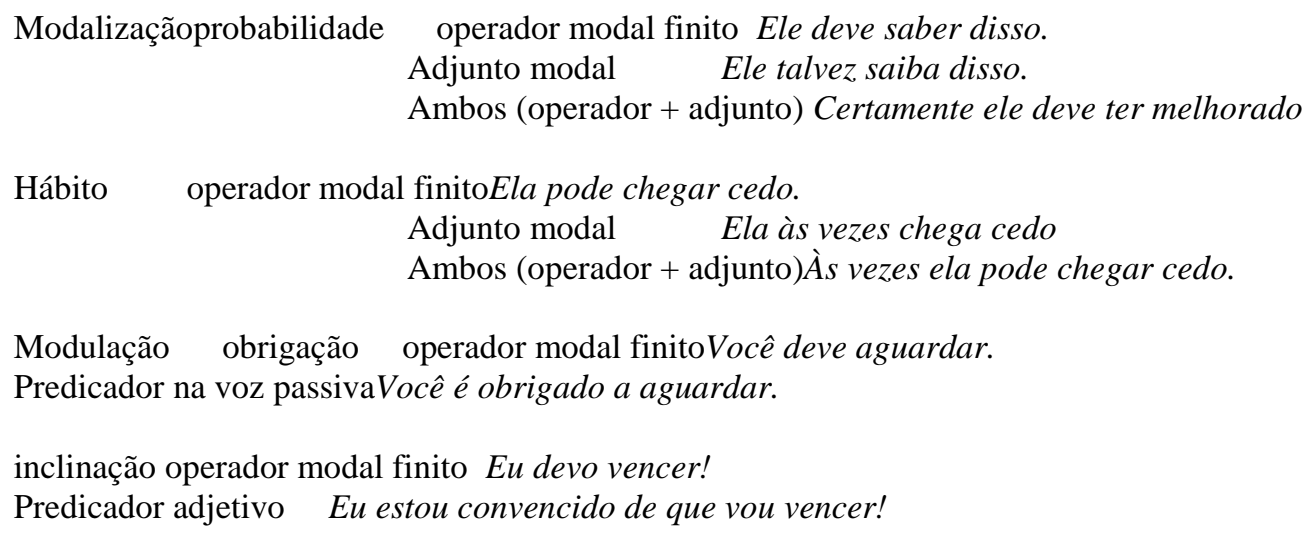

Os graus de modalização e modulação - alto, médio ou baixo são os valores básicos, graus de certeza e de pressão, e podem indicar o comprometimento do falante, ou seja, até que ponto ele se compromete com a validade do que é dito; e a responsabilidade pela atitude expressa, isto é, uma explicitação ou não da fonte (o falante / escritor, ou outro ser ou instituição) da atitude expressa. Também se pode estabelecer objetividade se se assume o ponto de vista como qualidade do evento em si, ou subjetividade quando o que é dito é caracterizado como um ponto de vista específico (Thompson, 1996, p. 62).

\section{c) Textual -A estrutura Tema e Rema}

Pensar a oração como mensagem significa admitir que ela tem uma estrutura temática, constituída de dois elementos: Tema e Rema. O primeiro é o elemento que serve como ponto de partida da mensagem, e sempre é, em inglês e português, posto à frente, e inclui tudo o que 
inicia a oração até seu primeiro elemento ideacional. No Tema está a maior parte do significado de uma oração. Isso significa que é dado a um elemento ou elementos um status especial na mensagem fazendo-o Tema. Em oposição, o Rema é o restante, o desdobramento da mensagem.

Como Tema, podemos ter um sintagma nominal, um sintagma adverbial e um sintagma preposicional.

Halliday (1994) caracteriza os Temas como marcados e não marcados. Estes são aqueles de ocorrência mais comum na língua, enquanto aqueles são os menos comuns ou que distinguem formas específicas. Independente de serem marcados ou não marcados, dois tipos de Tema são considerados pelo autor: o Tema simples sempre tem o elemento ideacional - o tópico - como central e único, mesmo que dois ou mais desses elementos estejam justapostos; e o Tema múltiplo é composto por elementos textuais e ou interpessoais junto com o tópico (elemento ideacional). A seguir apresento uma esquematização dos tipos de elementos temáticos que compões um Tema múltiplo mais prováveis de acordo com Halliday (1994).

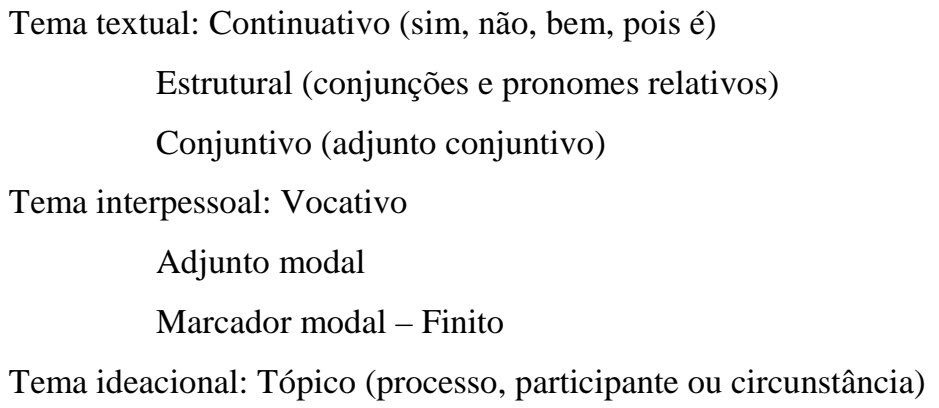

(Fonte: Halliday, 1994)

A importância do padrão Tema - Rema é mais evidente quando se considera a importância da escolha de elementos temáticos no desenvolvimento total de um texto. Por si só, esta escolha pode ser algo particular, mas tem um papel fundamental na maneira como o discurso se organiza, e é isto que constitui, de acordo com Halliday (1994), o "método de desenvolvimento de um texto” (p.61).

\section{ANÁLISE DISCURSIVA COM BASE EM LSF PROPOSTA POR MARTIN \& ROSE (2003)}

A Linguística Sistêmica-Funcional tem sido precursora (Magalhães, 2006) de abordagens de estudo do discurso, este visto como prática social. Halliday (in Collins \& Thompson, 2001) considera positivos os trabalhos que envolvem a análise linguística de 
maneira crítica, numa perspectiva política. Argumenta, no entanto, que para se entender a língua do poder, é preciso entender também o poder da língua. Assim sendo, análises discursivas de base Sistêmico-Funcional devem considerar a materialidade gramatical da língua para, a partir disso, construir interpretações. Halliday (1994) diz que a análise do discurso sem esta consideração é mera ilusão, limita-se a comentários do texto com apelos a aspectos e convenções não-linguísticas e acessíveis sem a gramática.

Uma proposta de análise discursiva com base na Linguística Sistêmica-Funcional é apresentada por Martin \& Rose (2003), brevemente descrita a seguir.

Esses autores pretendem a interpretação do discurso social e a análise de textos em contextos sociais. Para eles, a LSF, uma vez preocupada com a semântica do discurso, tenta também lidar com a complexidade do fenômeno a ser descrito, que é linguístico e ao mesmo tempo social. Os significados além do nível da sentença são foco principal da proposta, pois um texto é produzido interativamente na relação entre os interlocutores. Os autores acreditam que as metafunções se entrecruzam no uso da linguagem, e mesmo sendo analisadas separadamente por questões didáticas, ocorrem de maneira conjunta. Martin (1997) chama a atenção para o fato de um recurso discursivo de cunho ideacional, por exemplo, poder estar relacionado, em outro contexto específico, a relações interpessoais. Parece interessante, então, levar em conta o conceito de topologia (Martin, 1997; Martin \& White, 2005), ou seja, questões de proximidade entre os textos analisados e as categorias de análise.

Martin \& Rose (2003) apresentam sistemas discursivos ligados às metafunções e caracterizados a seguir:

a) valoração (do inglês “appraisal”): refere-se às atitudes negociadas num texto, sentimentos e valores construídos entre os participantes interlocutores. Sâo significados interpessoais que mostram a natureza interativa do discurso.

b) ideação (do inglês “ideation”): relaciona-se às atividades executadas, e como são descritas ou classificadas pelos participantes. O focoestá no conteúdo, portanto.

c) conjunção: também um tipo ideacional de significação, refere-se às conexões estabelecidas entre as atividades, reformulando, adicionando, seqüenciando, explicando. Conexões lógicas do tipo temporal, causal ou outras são formuladas.

d) identificação (do inglês “identification”): refere-se à introdução dos participantes (pessoas, lugares ou coisas) no discurso e sua manutenção. Trata-se de recursos textuais relacionados à forma como o discurso faz sentido ao receptor. 
e) periodicidade: é o fluxo da informação, envolvendo “camadas” de previsão e de consolidação dos significados. São tambémtipostextuais de significação.

Para cada um desses sistemas, são apresentados recursos de significação que permitem análises de textos em mais de uma perspectiva, às vezes. Para os autores, esses recursos de análises textuais (também caracterizados como “ferramentas”) podem ser usados para vários propósitos. Penso que esses recursos poderão nortear a análise de textos de divulgação e apresentação de livros didáticos produzidos e veiculados por autores e editores. A partir daí, então, espera-se ter uma idéia das representações construídas acerca do livro didático de inglês como língua estrangeira. Dado o limite deste trabalho, apresentarei apenas aspectos de valoração em conjunto com estrutura Modo / Modalidade, aspectos ideacionais / de representação, e periodicidade / textuais.

Para Martin \& Rose (2003) - também Martin (2000) - valoração é um sistema de construção de significados interpessoais, ou seja, as atitudes negociadas num texto, a força dessas atitudes e suas origens. Essas atitudes referem-se à avaliação das coisas, do caráter das pessoas e seus sentimentos. Para os autores, existem recursos na língua para expressar atitudes (que podem ser afeto, julgamento ou apreciação), além de recursos para amplificar essas atitudes expressas e atribuí-las a certas fontes. Dentro da categoria "atitude”, usa-se o termo “afeto” para se referir à expressão de sentimentos, o termo “julgamento” para avaliar caráter e conduta social, e “apreciação” para se referir ao valor atribuído às coisas. A expressão de atitude, amplificação e fonte acontece ao mesmo tempo, mas para expressar atitude há três formas, usadas uma a cada vez.

Com relação à ideação, Martin \& Rose (2003) dizem que o foco está no conteúdo do discurso, e são descritas as atividades de modo a mostrar como se classificam e são compostas. Para esses autores, não é a realidade pré-existente traduzida em palavras, mas há uma construção da experiência de realidade enquanto discurso, e para tanto contribuem as orações num texto verbal e os elementos dentro das orações. Os elementos básicos da significação ideacional são os participantes das atividades, os processos, as descrições destes e as circunstâncias em que ocorrem tais processos. Numa análise, o que se procura é estabelecer “de quem / que se fala”, “(sobre) o que se fala”, “como e que tipo de pessoa / coisa é esse (a) de que(m) se fala” e “em que circunstâncias” ocorre a atividade de que esse alguém / alguma coisa participa. Os processos, por sua vez, são categorizados em fazer, dizer, sentir e ser. O fazer representa as ações materiais, o dizer e sentir (considerados juntos) 
representam que há uma projeção de outro processo, e o ser focaliza a identificação, a existência, as características, a composição ou a classificação / pertencimento a um grupo.

Periodicidade, por sua vez, constitui-se da observação do fluxo da informação, a maneira como os significados são postos para que seja mais fácil para o receptor da mensagem apreendê-los. O termo "periodicidade” refere-se a uma regularidade do fluxo de informação, à capacidade de se criar num texto (oral ou escrito) um ritmo previsto.Contribuem para a compreensão da periodicidade a análise de palavras que nomeiam o discurso em si (ex. carta, apresentação, esse texto) - metadicursivas. Também tem importância para o entendimento da periodicidade a análise dos Temas das orações do texto e ou de partes do texto mostrando que o texto gira ou não em torno de um assunto específico, de que há uma continuidade ou uma descontinuidade da informação em torno de certo assunto. Martin \& Rose (2003) defendem a existência de hiperTemas na consideração e, escala maior das fases de um texto / discurso. São padrões que permitem prever o que acontece no texto e como a informação é apresentada em cada fase. Como hyperTemas, por exemplo, os autores citam os tópicos frasais, que podem dar detalhes tanto do campo da informação (field) como pode apresentar uma avaliação a respeito do assunto.

\section{A NOÇÃO DE GÊNERO DISCURSIVO NA LSF}

No contexto de cultura, mais abrangente e em maior nível de abstração, encontra-se o gênero que é definido por linguistas sistêmico-funcionais como processo social estratificado (em estágios) orientado para objetivos e, através desse processo, os sujeitos (também sociais) organizam suas vidas (Martin, 1997). O conceito de gêneros sugere que um texto se desdobra com funções diferentes a cada estágio de realização de um propósito comunicativo a partir de formas distintas, organizando-se, então, por estágios ou passos (Eggins\& Martin, 1996). Esta organização se configura como uma relação probabilística (e não determinista) que prevê alternativas inerentes na relação dialógica entre língua e contexto, o que significa dizer que os gêneros possuem unidades / elementos mais típicos e menos típicos, e que não necessariamente todos os elementos estarão presentes em todos os exemplares de um gênero. Isso acontece, por exemplo, com as apresentações de livros didáticos em manuais do professor, como exposto mais adiante.

Hasan (1989) defende a existência de uma unidade estrutural de textos em cada contexto de situação, uma estrutura genérica que representa a forma global da mensagem. $\mathrm{O}$ uso das formas linguísticas é moldado pelas características do contexto de situação e estas 
formam a configuração contextual do gênero (Hasan, 1989), ou seja, o conjunto de valores que realizam as variáveis de campo, relações, e modo. As características específicas da configuração contextual permitem afirmações e previsões sobre a estrutura de textos. Para Hasan(1989) pode-se de prever o que é obrigatório e possível em um texto exemplar de um gênero, e no gênero em si, se se tem em mente que elementos devem ou podem ocorrer, onde esses elementos devem ou podem ocorrer, e com que frequência os elementosdevem ou podem ocorrer.

A correlação direta entre as metafunções da linguagem e as variáveis do contexto de registro mostra, através do conceito de instanciação, que os significados são construídos / realizados de maneira que uma modificação num nível afetará todos os outros (Vian Jr \&Lima-Lopes, 2005). Isso significa que “escolhas no nível do contexto de cultura (gênero) refletir-se-ão nas escolhas no nível situacional (registro); tais escolhas, por sua vez, serão materializadas pela linguagem, uma vez que gênero e registro são conceitos abstratos”(Vian Jr \&Lima-Lopes, 2005: 44). O registro, então, é o ponto de partida para estudo de um gênero, pois é ele que traz elementos específicos da situação em que determinado gênero ocorre.

\section{A APRESENTAÇÃO DO LIVRO DIDÁTICO NO MANUAL DO PROFESSOR}

A apresentação de uma obra (literária ou não) constitui-se de uma introdução ao conteúdo dessa obra, seu(s) autor(es), e pode ser elaborada pelo autor ou outra pessoa competente para tal (Costa, 2008). A apresentação de um livro didático de inglês como língua estrangeira contida no manual do professor tem uma constituição similar. Nela, como acontece em apresentações desse tipo, segundo Costa (2008), estão os objetivos e as circunstâncias em que o livro foi produzido, o público a que se destina, filosofia / abordagem adotada.

Em se tratando especificamente de apresentações de livros didáticos de inglês como língua estrangeira contidos em manuais de professores, uma observação desse gênero em livros produzidos tanto no Brasil quanto no exterior mostra que, seja em textos em inglês seja em textos em português, algumas características são comuns. No entanto, os contextos de produção são diferentes. Os livros estrangeiros são produzidos em países anglófonos para um público alvo mais abrangente (de vários países em que a língua é ensinada) aprendendo inglês em contextos diversos, enquanto o livro nacional destina-se especificamente a alunos brasileiros que estudam inglês no sistema de ensino oficial. Com isso, essa apresentação do 
livro destina-se a professores que atuam em situações diferentes de ensino e aprendizagem, regidos por parâmetros específicos.

Porém, algumas semelhanças existem nas apresentações de livros nacionais e estrangeiros, independente da língua utilizada. A leitura de algumas apresentações em livros distintos mostra que há sempre:

- um destaque ao título da coleção apresentada, podendo ser através do uso de negrito, caixa alta, itálico ou fonte distinta do restante do texto;

- referências ao histórico de produção da coleção: como a coleção foi idealizada, por que, se se trata de uma nova edição;

- caracterização da coleção: número de volumes, quantidade de horas necessárias de estudo, relação e descrição dos componentes (livro do aluno, livros extra-classe, CDs, Fitas, DVDs, manual do professor, livro de exercícios, material extra para professor e aluno);

- caracterização do público-alvo: alunos de ensino fundamental (livros nacionais), alunos com mais de $\mathrm{x}$ horas de estudo, alunos que desejam atingir determinada proficiência;

- embasamento: teorias e ou crenças de ensino e aprendizagem de línguas em que se baseou a produção da coleção, ou as recomendações de documentos oficiais, tais como os PCNs (Brasil), ou European Framework (livros estrangeiros), ou ainda os níveis de proficiência de testes (FCE, Proficiencylevels).

Uma estrutura esquemática desse gênero, então, poderia incluir: identificação, histórico, embasamento, caracterização. Nessa estrutura esquemática, percebem-se os estágios com fins comunicativos em que o gênero se desdobra, variando a ordem em que isso acontece. O foco é a coleção em si, o que se revela nas escolhas linguísticas no âmbito ideacional, interpessoal e textual, conforme apresentado adiante.

Nessas apresentações pode ou não ocorrer o uso de imagens, o que não acontece com os textos a que este trabalho se refere.

Essas apresentações podem ser escritas pelos autores das coleções ou editores, nem sempre estando clara essa autoria. Mas, independente disso, óbvio é que os textos são destinados ao professor que utilizará o material, pois está dentro do manual destinado ao profissional.

Contudo, não se pode dizer que as apresentações são, como as contracapas, anúncios de propaganda. Mesmo que haja toda uma exposição positiva da coleção didática, ela se faz de maneira mais extensa (várias páginas em oposição ao espaço limitado de uma página da contracapa), direcionada mais claramente ao profissional, com termos e referências mais específicos do contexto de trabalho e de aprendizagem dos usuários. 
Se os usuários de uma língua organizam suas vidas através de gêneros, parece ser através das apresentações contidas em manuais endereçados ao professor que o autor ou editor da coleção didática transmite de maneira mais completa para o professor o que aquela obra representa para o contexto de ensino em que for usada, dito naquilo que ela veicula e no que direcionou sua abordagem e metodologia. Assim, pode ser através desse gênero que o professor terá mais informação (além do livro didático em si) acerca da pertinência de uso dessa obra em suas aulas, o que pode contribuir para decisões sobre uso ou não (adoção) desse material em aulas.

\section{Descrição do Corpus}

Como dito anteriormente, neste trabalho apresento um ensaio de análise de dois exemplares do gênero apresentação de livro didático de inglês contido em manuais do professor. São as apresentações das coleções MUST, da editora Richmond / Moderna, publicada em 2007 e da coleção PowerEnglishNewEdition, da editora Macmillan, publicada em 2008. Ambas as coleções são endereçadas a alunos brasileiros que estão matriculados do sexto ao nono ano do Ensino Fundamental, adolescentes de 11 a 14 anos. As duas editoras são de origem internacional (Britânicas) e há algum tempo também editam livros didáticos produzidos por autores brasileiros ou destes em conjunto com algum autor de outra nacionalidade, visando especificamente o ensino de inglês aos alunos brasileiros na escola regular. Em ambas as coleções, os textos aqui analisados pertencem ao manual do professor, que é encartado a um exemplar do livro do aluno, e os mesmos textos são encontrados em todos os volumes da coleção.

A apresentação da coleção MUST constitui-se de quatro páginas, todas com duas colunas de textos, e é assinada pela editora coordenadora da coleção. Vale ressaltar que a coleção MUST não possui um único autor, mas é um empreendimento idealizado pela própria editora Richmond/ Moderna no Brasil, e fruto do trabalho de diversos professores sob a coordenação editorial de uma responsável.

A apresentação da coleção Power English New Editon compõe-se de uma carta endereçada ao professor, sem assinatura, e introdutória do manual do professor (teacher'sguide), e da parte $\mathrm{I}^{5}$ do respectivo manual, intitulada “Conhecendo a coleção Power

\footnotetext{
${ }^{5}$ As demais partes referem-se às orientações e chave de respostas de cada unidade do livro, informações novas e recursos adicionais para o professor (testes, script de áudio, notas complementares), e uma chamada para a participação dos profissionais em associações profissionais e acadêmicas numa tentativa de formação de uma "rede de ação e transformação".
} 
EnglishNew Edition”. Neste caso, os textos não são assinados, podendo ter sido produzidos tanto pelos autores da coleção quanto por outras pessoas pertencentes ao quadro editorial.

\section{Procedimentos de análise}

Para a realização deste trabalho foram fotocopiadas três cópias de cada texto para que, em cada cópia, pudessem ser feitas as análises de cunho interpessoal, ideacional e textual. Manualmente foram marcados os elementos principais de cada sistema de significação, como descrito abaixo:

- interpessoal: foram observados e marcados os Modos oracionais, com os respectivos sujeitos das orações e os elementos finitos, assim como elementos de valoração indicadores de atitude (afeto, julgamento e apreciação), gradação e fonte / engajamento.

- ideacional: foram marcados e classificados os elementos verbais das orações numa tentativa de caracterizar os processos apresentados para se referir ao livro didático. Foi feita uma contagem para se ter noção de qual processo seria predominante em termos de quantidade. Certamente, essa análise nos levará mais tarde à consideração mais detalhada dos participantes e das circunstâncias ${ }^{6}$.

- textual: foram assinalados os elementos temáticos das orações que compõem os textos e observadas as ondas de informação, assim como aspectos relacionados à organização do texto em tópicos e ou parágrafos.

\section{ANÁLISE INTERPRETATIVA DE APRESENTAÇÕES DE LIVROS DIDÁTICOS EM MANUAIS DE PROFESSORES.}

\section{Sobre aspectos ideacionais:}

Em termos linguísticos, nessas apresentações ocorre uma predominância de processos materiais, seguidos de processos relacionais e existenciais (Halliday, 1994), pois é dito o que faz o livro / coleção ou seus elementos, o que ele é, tem, e o que há nele. Outros processos aparecem em menor quantidade e vão se referir mais especificamente a outros elementos do processo ensino-aprendizagem, como o professor e ou o aluno. A estes especificamente estão ligados os processos mentais e comportamentais que aparecem. São usados muitos adjetivos e grupos nominais extensos para caracterizar a coleção didática.

\footnotetext{
${ }^{6}$ Neste trabalho em específico, por questões de espaço, as circunstâncias não foram analisadas.
} 
No que se refere ao processo de fazer, nos textos em questão, o livro e ou seus elementos fazem algo (revisam o conteúdo, consolidam o que foi estudado, reúnem atividades, apresentam e praticam estruturas e vocabulário, sistematizam conteúdo, tornam algo possível, oferecem variedade, trazem dicas). Parece pertinente dizer que o participante que atua na aula é muito mais o livro ou seus elementos do que o aluno ou o professor usuários. Abaixo, segue um trecho retirado da apresentação da coleção MUST que mostra como o livro ou seus elementos são atores de ações:

\begin{abstract}
A partir do segundo volume, First Move pretende fazer uma revisão de conteúdo que foi abordado no volume anterior, gerando assim oportunidade para a consolidação do que foi aprendido. Esta unidade introdutória sempre se inicia por uma foto-história, seguida por atividades que envolvem a compreensão do texto e, a partir do volume 2, da caixa Keep in Mind, que traz dicas sobre gramática e vocabulário.
\end{abstract}

Observo, neste trecho e em outros dos textos em questão, que o ser humano que lida ou lidará com o material (professor, aluno, autor) pouco aparece como agente, podendo até mesmo ser omitido do discurso através do uso da voz passiva. Os verbos assinalados acima (todos denotam processos materiais) têm como participante Ator uma seção do livro didático ou atividades, e participantes humanos não aparecem. Chamo atenção para os verbos abordar e aprender que aparecem na voz passiva, sendo o Ator omitido (o que permite a voz passiva), mas permanece a circunstância em que o conteúdo foi abordado, ou seja, "no volume anterior”. Acrescento que, através de nominalizações, neste trecho, é também omitido o ser humano que pode fazer as ações de consolidar e compreender. É gerada uma oportunidade para consolidação do que foi aprendido, não uma oportunidade para o aluno consolidar o que aprendeu; são atividades que envolvem compreensão, não que necessitam que o aluno compreenda o texto.

Parece ser o livro o responsável pela aprendizagem do aluno, não necessariamente o próprio aluno ou o professor, e não parece haver consideração de que o professor possa ter importância nessa aprendizagem, para facilitá-la ou guiá-la. O professor pode utilizar recursos oferecidos pela coleção em determinadas circunstâncias (ver sobre modalização mais adiante). A coleção didática é, mais que uma ferramenta, representada como um agente produtivo do ensino-aprendizagem.

Percebo, também, que o livro didático está sendo caracterizado e identificado pelo fato de ser algo ou de alguma forma. Ressaltam-se seus elementos / partes que são identificados ou caracterizados de maneira a dar-lhes uma especificidade ou unicidade, da mesma forma que as qualidades do material ou de seus elementos. Exemplos disso são as orações abaixo, todas 
com verbos que denotam processos relacionais, em que há identificação e caracterização tanto do livro / coleção como de seus elementos.

\author{
MUST é uma coleção apresentada em quatro volumes ... (caracterização) \\ Um importante diferencial desta coleção é que ela possibilita que haja flexibilidade e dinamismo \\ em seu uso. (caracterização) \\ A coleção é composta por: (..) (caracterização por composição / posse) \\ Ao final das unidades 6 e 12, há um link para os Song Banks, que são atividades com canções \\ seguidas por sugestões de projetos. (caracterização / identificação) \\ O nível linguístico desses textos está ligeiramente acima do nível de produção esperado. \\ (caracterização) \\ O fio condutor destas leituras é a participação do aluno no mundo como cidadão. (identificação) \\ O objetivo desta seção é sempre dar... (identificação) \\ Além das respostas dos exercícios, o livro do professor contém um manual com orientações para \\ todas as atividades presentes no livro do aluno. (caracterização / composição)
}

As orações com processos existenciais contribuem também para a caracterização e identificação do livro / coleção didática, enfatizando seus elementos diferenciais e quallificadores.

Como premissa da coleção, ainda há a preocupação em integrar o ensino de inglês com o calendário escolar brasileiro...

...ela possibilita que haja flexibilidade e dinamismo.

....ao final de cada bloco encontra-se uma revisão.

A cada três unidades há uma consolidação...

A cada seis unidades há uma seção de Focus onGrammar,...

Além das 12 unidades básicas, há três seções adicionais ao final de cada volume.

... há muitas oportunidades de desenvolvimento das habilidades de compreensão e produção oral ao longo de toda a coleção.

\title{
Sobre aspectos interpessoais
}

As apresentações aqui analisadas mostram um caráter assertivo, pois o que se pretende transmitir ao professor leitor é uma certeza da boa qualidade do livro didático / coleção, e princípios bem fundamentados. Na maioria das orações, o sujeito é o próprio livro ou coleção ou elementos dele, os responsáveis pelas proposições feitas (Halliday, 1994), e usa-se o presente (tempo verbal do finito) na maioria das orações, o que implica numa certeza de que tudo que se diz sobre ele é verdade (asserção). Esta é a atitude da editora, entidade promotora da obra, e quem escreve é alguém que representa essa empresa, mesmo que ainda seja o autor. Seguem exemplos:

Must é uma coleção apresentada em quatro volumes e dirigida ao estudante do Ensino Fundamental 2.

Must apresenta a possibilidade de criação de um ambiente de estudo mais informal e dinâmico...

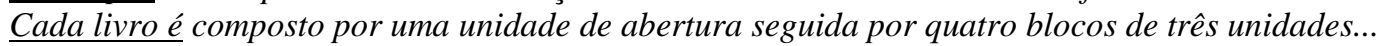


As atividades apresentadas nas unidades e a variedade de sugestões opcionais constantes no manual do professor e nos apêndices do livro do aluno contemplam diversos estilos de aprendizagem e permitem ao professor adequar seu planejamento....

Os exercícios propostos seguem uma gradação de dificuldade ...

A seção reproduz a letra de músicas conhecidas aconpanhada de atividades de compreensão e de discussão como abordagem intercultural.

Warm-up: contextualiza o conteúdo a ser trabalhado através de uma situação...

Time for fun: proporciona uma prática adicional através de atividades mais lúdicas.

Quando modalizadores são usados, eles indicam possibilidades de uso do material pelo professor dependendo do contexto de ensino em que atua, e é utilizado um modalizador de grau baixo (Halliday, 1994) - pode. Uma seção pode ser utilizada de duas maneiras, sugestões de testes podem ser reproduzidos e aplicados pelo professor, o aluno pode ouvir o CD em casa, o professor pode adaptar a programação idealizada na coleção. Isso indica que há uma possibilidade de aquilo poucas vezes acontecer, e que a maioria das proposições feitas (sobre o que o livro apresenta, o que os seus elementos promovem em aula, como são organizados, com que propósitos) são certamente o que acontecerá no processo ensino-aprendizagem.

Merece uma atenção especial aqui a carta endereçada ao professor que inicia a o Teacher'sGuide da coleção Power English New Edition. Nesta carta não assinada (portanto pode ser tanto dos autores quanto dos editores), é apresentada a premissa norteadora da concepção da coleção, o que se acredita que é possível acontecer um ensino de língua inglesa com qualidade na escola regular, e que o livro em questão pode contribuir para isso, pois é fruto do trabalho de quem acredita nisso. Em termos interpessoais, então, as afirmações também são feitas no presente, com caráter assertivo, uma tentativa de marcar uma certeza daquilo que ali se expressa, sem elementos modalizadores que indicariam possibilidade ou probabilidade de algo ser verídico. Também, não é o livro em si ou elementos dele que mais aparecem como sujeitos, mas sim o pronome "nós”, mas um “nós” cujo referente não se pode recuperar visto que não se assina a carta. Serão esse "nós" os autores, os editores, autores e editores em conjunto - responsáveis pela concepção e produção daquela obra? Ou ainda, estaria incluído nesse “nós” os autores, editores e professores / leitores que comungam das mesmas idéias? Interpreto que esse pronome promove uma proximidade entre escritores da carta e leitores (autores / editores e professores), contribuindo para que seja diminuída a distância entre esses interlocutores. Sendo esse pronome indicador de um sujeito humano, esse sujeito também é ator de processos materiais e sensor de processos mentais que ocorrem neste texto, tais como buscamos, fazemos, garantirmos, usarmos, lutarmos (materiais), acreditamos, refletirmos, gostaríamos, conhece, lembrar (mentais). 
A valoração do livro didático acontece de forma positiva, como de se esperar dada a função desses textos. Observei a predominância de termos que indicam apreciação do material, de acordo com o objetivo do texto de assegurar o professor de que adotar aquele livro é uma boa opção. Quando aparecem termos de gradação, estes reforçam algumas apreciações. Exemplos de apreciação (sempre positiva) são:

\footnotetext{
....as unidades apresentam uma linguagem acessível aos alunos ...

As atividades propostas apresentam níveis crescentes de dificuldade, tornando-se gradativamente maisdesafiadoras ... (sublinhado duplo para elementos que indicam gradação)

...atividades divertidas e envolventes.

Reciclagem freqüente do vocabulário novo em contextos interessantes.

$O$ item 18 deste Guide apresenta detalhadamente o conceito que temos de avaliação: um processo constante de observação ....
}

Não se evidenciam termos indicadores de afeto, pois o texto não expressa sentimentos com relação ao livro didático. Ao contrário, procura-se estabelecer uma objetividade também evidenciada na maneira como o autor / editor se compromete com as afirmações. Se o livro ou seus componentes são os sujeitos, eles são os responsáveis pelo que é dito, “eles realmente apresentam e promovem” o que está dito ali. É diferente, por exemplo, de orações como “Eu penso que / Nós acreditamos / Defendemos que as unidades apresentam ...”

\section{Sobre aspectos textuais}

Os sujeitos das orações que, com dito anteriormente, na maior parte das vezes são termos que indicam o livro / a coleção ou seus elementos, e ou aquilo que a coleção proporciona, também aparecem muitas vezes em posição temática, sendo textualmente evidenciados. Esses elementos dos livros didáticos ou aquilo que ele traz ocorrem também como sintagmas adverbiais ou preposicionais ou orações adverbiais que indicam circunstâncias em posição temática. A seguir, são apresentados alguns exemplos:

Tema sujeito da oração (livro / coleção, elemento do livro ou o que ele proporciona)

MUST é uma coleção apresentada em quatro volumes...

Cada livro é composto ....

O livro do aluno caracteriza-se por introduzir as unidades...

Cada volume é dividido da seguinte forma.

Cada volume de Power English New Edition é estruturado...

Organizada em quatro volumes, Power English New Edition é uma coleção...

A unidade final de cada volume, - a Unit 12 0- contém ...

Extra: apresenta e pratica diversos tipos ...

Time for vocabulary: reúne atividades variadas ...

O item 18 deste Guide apresenta detalhadamente ...

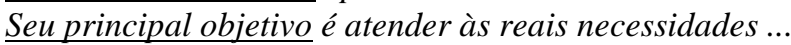


Esse trabalho com diversidade de gêneros permite que o aluno ...

A prática das habilidades é totalmente integrada

Os temas abordados refletem as áreas de interesse ...

Todas as seções do livro têm seu objetivo ...

Tema circunstância (Sintagma adverbial, sintagma preposicional ou oração adverbial)

Para que o conteúdo e o formato da obra pudessem de fato reproduzir a voz do professor foram entrevistados diversos professores...

Por meio de situações da vida real, as unidades apresentam uma linguagem acessível...

A partir de recortes dos textos, os alunos são levados a observar ....

A partir do segundo volume, First Move pretende fazer ...

Em cada unidade, são encontradas seções específicas para o desenvolvimento ...

Partindo de uma sugestão de WarmUp, os alunos inicialmente participam...

A cada três unidades há uma consolidação ...

A cada seis unidades há uma seção de Focus onGrammar ...

Além das 12 unidades básicas há três seções ...

Por meio de dálogos apresentados, os alunos ...

Ao final de algumas unidades, após a leitura os alunos encontrarão ...

Esse fato demonstra que o texto é todo organizado em torno do livro didático apresentado, e evidencia ainda mais o propósito de apresentar o material em questão fixando sua existência e de seus componentes. Ainda há ênfase ao título da coleção - que também acontece pelo uso de fonte diferente sendo caixa alta ou negrito e itálico. A mesma ênfase e fixação junto ao professor-leitor acontece com relação ao que o livro traz (unidades, atividades, notas, livro do professor, workbook) e proporciona (prática de habilidades, organização, trabalho com diversidade, ênfase).

No caso da carta que inicia o Teacher'sGuide da coleção Power English New Edition, diferentemente do que acontece com o texto a respeito do livro em si, a ênfase está na figura do professor receptor do manual a ele endereçado, consequentemente dos textos ali contidos, professor este que aparece como Tema de algumas orações. Como dito a respeito do uso de “nós”, e parece ser usado para promover uma proximidade entre escritores da carta e leitores (autores / editores e professores), diminuindo a distância entre esses interlocutores. Assim, como sujeito, é também Tema em grande parte das orações, e mesmo quando omitido, é recuperado pela terminação verbal, evidenciando-se como Tema Marcado. Também aparecem como Tema, elementos humanos (professor e aluno).

(Nós)Acreditamos, sim que é possível ...

(Nós)Fazemos tal afirmação ...

(Nós)Sabemos que, se o professor...

....o professor quer ensinar ...

Como professores de língua e metodologia que somos, buscamos na nossa experiência ... 
Observo ainda uma preocupação por parte do produtor dessas apresentações (que como dito anteriormente pode ser o autor ou editor do livro didático) de fazer com que a leitura dele não seja demorada, e por isso os textos são organizados em parágrafos não muito longos, em forma de tópicos. Na apresentação e caracterização de elementos da coleção e partes das unidades, é usado o recurso de negrito para evidenciar o elemento sobre o qual se escreve naquele momento, evidenciando mudança de tópico no texto. A divisão em tópicos faz com que a informação fique mais fluida, mais organizada didaticamente deixando a entender, também, que há a intenção de que o uso do manual e do livro pelo professor não precise tomar tempo. Fazem parte dessa estruturação e contribuem para que ela ocorra as nominalizações ${ }^{7} \mathrm{e}$ ainda a possibilidade de omissão de verbos, como em:

Situational Banks - Uma ou duas páginas referentes a cada bloco de três unidades regulares, com o objetivo de explorar mais profundamente a comunicação oral, baseada nas funções do idioma apresentadas nas unidades.

Neste caso, omite-se o verbo “ser” para definir Situational Banks que está em negrito, e os verbos utilizados na definição estão nas formas nominais: infinitivo e particípio. No exemplo a seguir, observo o uso de nominalizações na organização em tópicos para se referir às ações de embasar, orientar, praticar.

As notas para o professor e o Teacher'sGuide são importantes porque fornecem, dentre outras coisas:

(...)

- Embasamento teórico e orientações para o professor relacionadas a uma ampla variedade de tópicos.

- Informações complementares sobre os temas e assuntos introduzidos no livro.

- Idéias para prática adicional. ...

Ressalto, nesta seção, a organização na forma de perguntas e respostas do texto sobre a coleção Power English New Edition. Esta estratégia promove também o tipo de organização a que me referi nos parágrafos anteriores - fluidez e rapidez para leitura. Além disso, essa forma de organizar a mensagem parece também uma tentativa de fazer o leitor - professor se sentir dentro do texto. Em termos interpessoais, é também uma maneira de diminuir a distância entre produtor e receptor do texto, mostrando que aquelas seriam as perguntas de

\footnotetext{
${ }^{7}$ Nominalizações são entendidas por Halliday (1994) como metáforas gramaticais de cunho ideacional, e no caso das apresentações aqui expostas, elas contribuem para que a mensagem seja mais concisa.
} 
professores com relação à obra, e que os produtores do texto a previam porque também conhecem o ofício de ser professor, seus questionamentos e preocupações ao se conhecer uma obra didática para ser utilizada. ${ }^{8}$

Na carta que inicia o manual do professor desta coleção também é utilizado esse recurso de organização, estando em negrito e como subtítulo orações que indicam os princípios norteadores da coleção a serem explicados em um ou no máximo dois parágrafos.

Nesta carta, assim como no texto introdutório (Características Gerais da obra) da coleção Must, percebo uma organização maior da mensagem com hiperTemas. No caso da carta, que introduz especificamente o manual do professor, o primeiro parágrafo inicia-se com Este Teacher'sGuide, retomado como Tema ao final do texto na forma de Este Guide. O mesmo acontece com o texto sobre a coleção Must, pois o primeiro parágrafo inicia-se com MUST é uma coleção...e o último retoma isso repetindo o título da coleção. É como se houvesse todo um empacotamento (Martin \& Rose, 2003) da informação ali em torno do tema central: o livro ou o livro do professor que estão sendo apresentados ao professor leitor.

\section{CONSIDERAÇÕES FINAIS}

Neste trabalho, analisei apresentações de livros didáticos de inglês localizadas em manuais endereçados a professores (os livros do professor) à luz dos conceitos da Linguística Sistêmico-Funcional. O arcabouço teórico inclui a visão sociossemiótica da linguagem apresentada pela LSF, as metafunções da linguagem, a noção de contexto de situação e de cultura, os sistemas de significação textual, ideacional, interpessoal e textual, parte da proposta de análise discursiva de Martin \& Rose (2003), e o conceito de gêneros discursivos proposto por adeptos da Linguística Sistêmica Funcional.

Um ensaio de análise discursiva de dois exemplares do gênero, com base na LSF, foi apresentado. Os textos utilizados (de livros didáticos de inglês produzidos no Brasil) refletem o uso real da língua portuguesa com o intuito de agir na sociedade brasileira, apresentando o livro didático em questão, esclarecendo e orientando professores a seu respeito. Aspectos ideacionais, interpessoais e textuais são reveladores dos objetivos desses textos: não apenas apresentar, mas também enfatizar e reforçar a existência da coleção apresentada, suas características, seus aspectos positivos, o que promove e proporciona. Isso contribui para

\footnotetext{
${ }^{8}$ Observo, então, que recursos ideacionais, interpessoais e textuais estão extremamente ligados na constituição e construção dos significados num texto. Um elemento não é apenas ideacional, interpessoal ou textual, mas está relacionado às diferentes metafunções ao mesmo tempo, contribuindo para a construção de significados em âmbitos diferentes de uma só vez.
} 
criar, junto ao professor leitor, uma imagem de que o livro é um promotor de ações, um agente ativo no processo ensino, pois é ele ou seus elementos que fazem, proporcionam, praticam, tornam possível, contextualizam, seguem, respeitam. Essas idéias são transmitidas e organizadas no texto de modo a deixar no leitor - professor uma segurança, afirmando, mostrando fatos, e não possibilidades. Coloca-se em evidência a importância do material apresentado para uma determinada realidade pedagógica, organizando a mensagem de modo a mostrar essa ênfase em um texto coeso, conciso e objetivo.

Muito poderia ser dito com relação a esses textos e por ora não é possível dada a extensão que este trabalho já tem e a necessidade de mais leituras para aprofundamento da análise que apresentei ${ }^{9}$. Como pesquisador, penso serem necessáriasmais reflexões sobre estes e outros manuais direcionados a professores.

\section{REFERÊNCIAS BIBLIOGRÁFICAS}

Collins, H. \& Thompson, G.(2001). Interview with M. A. K. Halliday, Cardiff, 1998.In: DELTA, vol. 17(1), São Paulo, versão online, acessado em 20 / 07 / 06.

Costa, S. R. (2008). Dicionário de Gêneros Textuais. Belo Horizonte: Autêntica Editora.

Cunninsworth, A.(1995)Choosing your Coursebook. Oxford: Heinemann..

Eggins, S (1994). An Introduction to Systemic Functional Linguistics. London \& New York: Continuum. Cap 1 An overview of the systemic functional approach, pp 1-24.

Eggins, S\& Martin, J. (1996) Genres and Registers of Discourse. In.: T.A. van Dijk (ed.) Discourse: a multidisciplinary introduction. London: Sage, pp 230-256.

Halliday, M.A.K. (1994)An Introduction to Functional Grammar. $2^{\text {nd }}$ ed. London: Arnold

Halliday, M.A.K. (1989). Context of Situation. In.: Halliday, M.A. K \&Hasan, R. Language, context and text: aspects of language in social semiotic perspective. Oxford: Oxford University Press, pp3-14

Halliday, M.A.K. \&Mathiessen, C. (2004)An Introduction to Functional Grammar. $3^{\text {rd }}$ ed. London: Hodder Arnold, Cap 1 - The Architecture of Language, pp 3-36

Hasan, R. (1989)The structure of a text. In.: Halliday, M.A. K \&Hasan, R. Language, context and text: aspects of language in social semiotic perspective. Oxford: Oxford University Press, pp 52-59.

\footnotetext{
${ }^{9}$ Percebo, por exemplo, que o conceito de metáfora gramatical cunhado por Halliday (Halliday, 1994) pode ser útil e necessário visto que há um uso considerável de nominalizações nos textos aqui analisados, como já observado em outros que comporão o corpus da pesquisa de doutorado.
} 
Magalhães, C. (2006) Percursos das abordagens discursivas associadas à Lingüística Sistêmica Funcional: Revista Multidiscursos.Belo Horizonte: Faculdade de Letras da UFMG,mimeo.

Martin, J. R. (1997) Analysing genre: functional parameters. In.; F Christie \& J R Martin (Eds.)Genre and Institutions: social processes in the workplace and school. London: Cassell. pp. 3-39.

Martin, J. R. (2000) Beyond Exchange: Appraisal Systems in English. In.: Huston \& Thompson (eds). Evaluation in Text. Oxford: Oxford University Press, pp 142-175

Martin, J. R\&White, P. (2005) Introduction. In.: The language of evaluation: Appraisal in English. New York: Palgrave Macmillan, pp 1-41

Martin, J. R. \& Rose, D. (2003)Working with Discourse: meaning beyond the clause. London and New York: Continuum.

Neves, M. H. M. (2004)A Gramática Funcional. São Paulo: Martins Fontes.

Schlee, M. B. (2006)O finito e a modalidade em editoriais de jornal. Proceedings 33rd InternationalSystemicFunctionalCongress, São Paulo: PUC-SP, p.1007-1020, disponível em http://www.pucsp.br/isfc/proceedings/Artigos\%20pdf/50n_schlee_1007a1020.pdf,Acesso em $14 / 04 / 2009$.

Thompson, G. (1996) Interaction in the clause: the interpersonal metafunction. In.:IntroducingFunctionalGrammar. London: Arnold, pp 38-75

VianJr, O. \& Lima-Lopes, R. E. (2005) A perspectiva teleológica de Martin para a análise de gêneros textuais. In.: Meurer, J.L.; Bonini, A.; \& Motta-Roth, D. (org) Gêneros - teorias, métodos, debates. São Paulo: Parábola Editorial, pp29-45.

\section{Obras didáticas consideradas:}

Granger, C \& Almeida, M R. (2008) Power English NewEdition.1 Teacher's Guide. São Paulo: Macmillan do Brasil.

Pimentel, L (ed.) (2007) MUST 1 Livro do professor. São Paulo: Richmond / Moderna.

\section{O AUTOR}

Renato Caixeta da Silvapossui graduação em Letras pela Universidade Federal de Minas Gerais (1992), mestrado em Estudos Linguísticos pela Universidade Federal de Minas Gerais (1998) e doutorado em Letras (Estudos da Linguagem) pela Pontifícia Universidade Católica do Rio de Janeiro (2012). Desde 1997 é professor do Centro Federal de Educação Tecnológica de Minas Gerais, atuando no Ensino Médio Profissional, em cursos de graduaçãoe de pós-graduação.

E-mail: rencaixe@yahoo.com.br 